InOedia $\quad \begin{aligned} & \text { InMedia } \\ & \text { The French Journal of Media Studies }\end{aligned}$

$4 \mid 2013$

Exploring War Memories in American Documentaries

\title{
Control Room and the Staging of War
}

\section{Barry Mauer}

\section{(Q) OpenEdition}

\section{Journals}

Electronic version

URL: http://journals.openedition.org/inmedia/680

DOI: 10.4000/inmedia.680

ISSN: 2259-4728

\section{Publisher}

Center for Research on the English-Speaking World (CREW)

\section{Electronic reference}

Barry Mauer, «Control Room and the Staging of War », InMedia [Online], 4 | 2013, Online since 16

November 2013, connection on 08 September 2020. URL : http://journals.openedition.org/inmedia/ 680 ; DOI : https://doi.org/10.4000/inmedia.680

This text was automatically generated on 8 September 2020

(c) InMedia 


\title{
Control Room and the Staging of War
}

\author{
Barry Mauer
}

The description of a war can be a weapon of war. ${ }^{1}$

1 Jehane Noujaim's documentary, Control Room (2004), focuses on the Al Jazeera news channel in the early days of the Iraq War. Control Room answers Donald Rumsfeld's charge that Al Jazeera sides with terrorists; Control Room shows Al Jazeera's staff faithfully translating the pronouncements of Bush administration figures, striving for balance, and putting themselves at great risk to get the stories that western journalists were not covering. In the film's darkest sequence, we learn that Tarek Ayyoub, an Al Jazeera reporter, died from an American bomb attack while he was on the job in Baghdad, raising the question of whether the U.S. targeted Al Jazeera's offices in order to silence the station. Control Room was not filmed in Baghdad, however, but in Qatar, the location of U.S. Central Command (aka CentCom) and Al Jazeera headquarters. Though the military conflict between the U.S. and Iraq did not extend there, Qatar became a battlefield of representation as Al Jazeera and CentCom battled each other for control over representation.

2 By focusing on the contested arena of media representation during the early days of the Iraq War, Noujaim's Control Room makes a vital contribution to the debate over media producers' relationships to centers of political and military power in a time of war. The film demonstrates that we need ways to navigate the flood of misinformation and competing points of view that surround us. Like other documentaries that dealt with media representations of the Iraq War, such as Michael Moore's Fahrenheit 911 (2004), Danny Schechter's WMD: Weapons of Mass Deception (2004), Jeremy Earp and Sut Jhally's Hijacking Catastrophe: 9/11, Fear \& the Selling of American Empire (2004), John Pilger's The War You Don't See (2010), and Robert Greenwald's Uncovered: The War on Iraq (2004), Control Room shows us symptoms of a damaged public sphere and a mass media that fails to do its public duty. What distinguished Control Room from these films is its cinéma vérité style; there is no narrator to provide an argument about the war. Rather, Control Room relies on arguments made by its subjects and on the power of editing to make its case. 
This essay analyzes Control Room in order to gauge the power of documentary to restore the public sphere. What factors shape the making of news during times of war? How can viewers learn to navigate the competing media frames and narratives about war? How can dedicated documentarians make more democratic a public sphere that has been badly damaged by corporate media consolidation and government propaganda? Finally, can rhetoric and poetics shed light on the choices made by documentary filmmakers during times of war and the ways in which target audiences are expected to make sense of their films?

4 Rhetoric and poetics, I argue, can help us understand the arena of public discourse, supplementing political media analyses proposed in the works of Jean Baudrillard and others. Noujaim's film fosters attention to the kinds of pseudo-events discussed by Baudrillard. For example, the film shows uncritical American media outlets repeating the packaged statements of military officials about the announced "rescue" of Private Jessica Lynch. ${ }^{2}$

5 Institutional analyses, such as the entertaining and enlightening work of Herbert Schiller, examine the structures of media entities; who owns the media? How does it "package consciousness"? ${ }^{3}$ These are worthy questions and Schiller provides an excellent critique of the ways in which corporate control of the media has stifled dissent. Schiller, who wrote much of his work before the days of global telecommunications, was skeptical of the power of independent media to challenge corporate control because, he argued, it must still abide by the rules of profitability in a capitalist society. ${ }^{4}$ Nevertheless, independent media has grown in recent years and represented a significant challenge to the Bush administration. Also a challenge to the Bush administration was foreign media, as evidenced by the efforts the administration took to marginalize, discredit, or bomb these sources, especially Al Jazeera, during the selling and prosecution of the war. To understand how independent and foreign media present challenges to government and to media conglomerates in the U.S., I turn to Douglas Kellner's view that media is a contested arena that requires audiences to learn critical tools in order to understand it. ${ }^{5} \mathrm{~A}$ textual analysis of Noujaim's film reveals the ways in which she seeks to educate the viewer to decipher the making and framing of the news.

6 Bill Nichols puts Aristotelian rhetoric to good use in his discussion of the effects of documentary. ${ }^{6} \mathrm{He}$ reminds us that the categories of proofs, including ethical, emotional, and demonstrative, shape the documentarian's filmmaking choices in an attempt to persuade audiences of the filmmaker's argument. By going "backstage" to show how media managers stage war for mass consumption, Control Room stages the media contest in a self-reflexive gesture. If we accompany our viewing of Control Room with lessons about rhetoric and poetics-which aids in understanding the staging of war as drama-we can become thoughtful media critics and engage effectively in the process of making the public sphere more democratic.

7 Control Room shows us journalists and political players engaged in staging our images of war. To stage a war is to arrange the combatants before the battlefield. Another meaning of the word staging involves the presentation of war to the public. Like theater, war requires settings and players and the various media outlets portray these elements in different ways. Are we witnessing liberation from a brutal dictator or the hostile takeover of a sovereign country? The interpretation depends on which channel we watch and on our ideological assumptions. The outcome of the military contest 
between Saddam's forces and the U.S-led coalition may have been obvious from the start, but the control of the war's narrative was not. Later in the war, as the search for Saddam's alleged WMD failed, stories about torture at Abu Ghraib emerged, and the insurgency intensified, the U.S. government lost more control over the narrative.

\section{Dramatis Personae}

8 Control Room largely follows cinéma vérité conventions, capturing events on the fly, though it does employ some montage to great effect in rendering the director's answers to Rumsfeld's charges against Al Jazeera. Though cinéma vérité does not stage the events it captures, I argue in this section, following the work of Erving Goffman, that life follows art and that we can understand the real-life conflicts captured by Noujaim in dramatic terms.

Control Room is not obviously a drama, yet it has dramatic features. The three main characters in the film-Al Jazeera senior producers Hassan Ibrahim and Sameer Khader, and U.S. Central Command Press Officer Captain Josh Rushing-all media workers, are engaged in a dramatic contest of representation, and the stakes of the contest are enormous. Is the war justified? Is the U.S. presence in Iraq an act of liberation or a hostile invasion? Is Al Jazeera a news station or a source of propaganda? Control Room posits that the war is not justified, that the U.S. presence in Iraq is a hostile invasion and that Al Jazeera is a source of news, but it makes its arguments through demonstration, dialogue, and editing rather than through on-screen or voice-over narration.

The characters in Control Room are not actors, and the action is not scripted. Yet a drama perspective reveals how struggles for power and control that are played out in real life owe something to fictional drama and vice-versa. Bill Nichols' concept of "virtual performance" is useful here:

Virtual performance presents the logic of actual performance without signs of conscious awareness that this presentation is an act ... Virtual performance, or the everyday presentation of self, derives from a culturally specific system of meanings surrounding facial expressions, changes of vocal tone or pitch, shifts in body posture, gestures, and so on-those very elements that actors train themselves to control at will. ${ }^{7}$

11 The bridge between reality and drama is even stronger in the sociological work of Erving Goffman on character contests. ${ }^{8}$ Goffman argues that people judge the behaviors of others in real life using the same standards by which they judge characters in fictional drama. Thus real life actors construct and/or frame dramatic encounters to showcase the character traits they wish their audience to attribute to them.

A special type of character contest, called a run-in, occurs when two characters want opposing outcomes and neither character backs down. Goffman states that run-ins are played for a number of stakes: to gain attributes of "good character" (such as courage, honesty, fidelity, etc.) by acting out those attributes; to maintain self-control; to establish and maintain boundaries; to define the self at the expense of others; and to decide who gets to have their way. Additionally, such contests can have numerous outcomes: an overmatched player can lose a contest but win character through bravery, grace, or irony; a well-matched but honorable player can win character by losing a run-in to an opponent who stoops to dirty tactics; and a player who wins 
against a weaker opponent may lose character by acquiring the traits of a bully. The determination of who "wins" a character contest belongs to the audience, who judges not only the manifest outcome, but also the respective strengths and weaknesses of the agonistes and the fairness of the tactics they use.

At the risk of accepting the argument that corporations and government entities are people, I argue that Al Jazeera and CentCom were agonistes in a character contest over the representation of the war in Iraq. During wartime, mass media corporations and government agencies have the means to affect the audience's picture of the military and ideological struggle. By shaping the narrative, such as by censoring information about the tactics of one side or by overestimating the strengths of the other, these entities can tip the audience and thus the outcome of the military and ideological character contests. Since many U.S. media corporations became enmeshed and embedded with the Pentagon, Al Jazeera's fight for an alternative view put it in direct conflict with the Pentagon.

14 Control Room portrays Al Jazeera as the overmatched player. We see Al Jazeera bravely defend itself against unethical and far stronger opponents, while Donald Rumsfeld and other Pentagon officials use censorship and lies to manipulate the media picture. Rumsfeld, in turn, openly accuses Al Jazeera of lying, broadcasting anti-American propaganda, and violating proper journalistic conventions against showing prisoners and casualties.

Though war may appear to be a contest in which there are no rules other than brute force, our understanding of war is highly structured according to the dramatic principles outlined by Goffman. The Bush administration sold the Iraq war to the public primarily as a war of self-defense against Saddam Hussein's WMD and his supposed ties to Al Qaeda, and to a lesser extent as a war of liberation against a tyrant bent on creating an empire in the region. Throughout much of the world outside the U.S., these justifications for war were met with near total rejection. Clearly, however, the Bush administration succeeded in launching the war because its false justifications were accepted to a large extent by U.S. media and thereafter by much of the American public. ${ }^{9} \mathrm{Al}$ Jazeera's Ibrahim states, however, that he has absolute faith in both the U.S. Constitution and the American people to correct the flawed policies of the Bush administration.

Self-defense was the rhetorical glue that held American public opinion together on the eve of the war. As Al Jazeera senior producer Sameer Khader opines in Control Room, "The American media were hijacked by some people within the administration ... to make the Americans always feel that they are under siege and there is a threat and this threat was represented by Saddam Hussein and Iraq." A war of self-defense is easy to justify and we can understand the nature of its appeal by describing it in the terms Goffman provides. Self-defense implies the defender is of good character, especially if the effort is to defend other weaker members of the group. ${ }^{10}$ It implies the defender has maintained self-control and has only struck back as a last resort in the face of imminent attack. A war of self-defense seeks to establish and maintain boundaries, such as those boundaries protecting security and law, against an enemy that would subvert them. It can define the self at the expense of others, which works extremely well if you can portray the others as evil and yourself as good. And clearly, a war of selfdefense can determine who gets to have their way. While Control Room does not 
explicitly discredit each of the Bush administration's claims to self-defense, it clearly does not accept them either.

The Bush administration's argument that the war in Iraq was in self-defense was never very strong: Saddam had never attacked the U.S.; there was no proof he possessed either weapons of mass destruction or had any ties to al Qaeda; and his military had been greatly degraded by the previous Gulf War, years of sanctions, and a strictly enforced no-fly zone. Nevertheless, much of the American public, as a result of propaganda, came to believe Saddam was a threat to them. Other documentaries, such as Michael Moore's Fahrenheit 911, deconstruct Bush's pro-war arguments, but Control Room presents a more ground-level view of the media war.

Al Jazeera entered the media agora, and by doing so, it offered viewpoints that contrasted with those of most American corporate media outlets. The American media, with few exceptions, had fallen in line behind the Bush administration by cheerleading the war and self-censoring. The battle for public opinion engaged by Al Jazeera was fought largely over the question of media conventions. Al Jazeera showed dead and grieving civilians, dead U.S. troops, and captured U.S. prisoners of war. American TV rarely showed these images, but why? Did the U.S. government control the American media? ${ }^{11}$

19 Control Room uses archive footage to deconstruct the Bush administration's and Pentagon officials' war discourses; they blamed Al Jazeera for using dirty tactics, and thus fighting unfairly in the war of representation. A key issue in Control Room is Al Jazeera's portrayal of civilian casualties. Rumsfeld states that Arab television showed things that are "flat not true" ${ }^{12}$ in order to incite against the Americans. Khader counters Rumsfeld by pointing to a picture of a wounded child on Al Jazeera, "Rumsfeld called this incitement. I call it true journalism."

Another key issue discussed in Control Room is whether Al Jazeera was wrong to have shown footage of captured American POWs, which was videotaped by Iraqi officials. In the film, we see George W. Bush exiting his helicopter, preceded by his dog, then his wife Laura. Bush answers reporters' questions about U.S. prisoners. Bush says he "expects them to be treated humanely, and uh just like we're treating the prisoners that we have captured humanely." ${ }^{13}$ We then see a video of a U.S. prisoner. An offscreen person with an Arabic accent asks, "Why did you come from America?" "Because I was told to come here." "You come to kill Iraqi people?" "No. I come to fix broke stuff."

21 Al Jazeera senior producer Hassan Ibrahim says, "Rumsfeld is saying that parading the footage of these captives is a violation of the Geneva Convention." He adds, "What do you call Guantanamo Bay, what you call the Iraqi soldiers parading yesterday on American television, what do you call bombing a city without authorization from the UN Security Council?" Noujaim cuts to Joanne Tucker, a manager of Al Jazeera, being interviewed by an American journalist, who tells her there is a lot of pressure on $\mathrm{Al}$ Jazeera to withdraw images showing captured U.S. troops. Tucker argues for showing the footage, stating this "is not a clean war." Asked if Al Jazeera is capable of being objective, she replies, "Are any U.S. journalists objective about this war?" Tucker points out that Al Jazeera was criticized for showing images of captured and dead U.S. troops, but "if there were true neutrality, all information from all sides would be welcomed."

Next Noujaim cuts to CentCom's Captain Rushing who takes up the other side of the debate by stating that the images of dead U.S. soldiers on Al Jazeera, which Noujaim 
shows while he speaks, made him sick and that U.S. news does not show those kinds of images. Yet Rushing adds that the images of wounded Iraqis he saw the following night on Al Jazeera, which Noujaim also shows while he speaks, did not bother him as much, and that he is able to imagine himself in the shoes of Al Jazeera staff having the opposite reactions. In a moment of profound self-realization, he admits of his partisanship, "It makes me hate war."

Compared to Captain Rushing, a model of reasonableness and self-awareness ${ }^{14}$ Donald Rumsfeld appears to be little more than a two-dimensional villain from a Hollywood melodrama. One difference between a scripted melodrama and reality is that in Control Room there is no poetic justice in which the wicked are punished. "We are dealing with people who are willing to lie to the world to make their case," Rumsfeld says. Yet Rumsfeld remains unpunished for lying about Iraqi WMD and for ordering the abusive treatment of prisoners at Abu Ghraib, Guantanamo, and other sites. Instead, he continues to justify his case for war.

Control Room repeatedly emphasizes how small Al Jazeera is compared to the might of the U.S. military. ${ }^{15}$ It sets up its audience to "root for the little guy." The Al Jazeera staff members are hardworking and ordinary. They are overweight, balding, chain smoking, unglamorous. They seem particularly vulnerable as well. The beginning of Control Room foreshadows the death of Tarek Ayyoub many times. We see reporters donning their new "working gear": flak vests and helmets. Mohamed Jasem, general manager of Al Jazeera, tells us that the station gave their locations in major Iraqi cities to Washington and to the Pentagon. Noujaim cuts to shots of bombs falling. We see an Al Jazeera reporter on the roof of a building. Explosions occur behind him. He ducks. The camera pulls back; we realize the image is on a television screen. We see a radio operator in $\mathrm{Al}$ Jazeera's office yelling "Baghdad? Baghdad?" into his microphone. We hear no answer. This moment occurred at the beginning of the U.S. bombardment, but it was not the day Tarek Ayyoub died. Control Room dramatizes the work of journalists in a war environment, thus framing them as heroes too.

The character conflict within Control Room reaches its crisis at the moment of Ayyoub's death. A crisis is the point when the drama's protagonists, in this case Al Jazeera's Khader and CentCom's Rushing, face their greatest challenges. Khader makes clear he sees the attack as the Bush administration's message to the station that it was being targeted because it is "not one hundred percent against Saddam." ${ }^{16}$ But Khader is not deterred. He says of the killing of Ayyoub, "For me it was a crime that should be avenged, or at least investigated." A press release from the U.S. states that coalition forces came under significant heavy fire from the Al Jazeera building, but the time leading up to the attack was caught on video. No weapons fire from the building is apparent. We see a plane turn and fly toward the building and unleash its payload. Control Room uses visual proof, where available, to stand up against verbal arguments.

CentCom's Captain Rushing faces a crisis too at this point. He denies that the American bombing that killed Tarek Ayyoub was aimed at silencing Al Jazeera. He states that if the U.S. had wanted to shut down any media coverage, the army could have done it. Rushing also doubts the message was to turn the media down because the end result of the bombing was to turn it up. Yet an Al Jazeera staffer, commenting later, states that potential interview subjects said they would not speak to him after the attack, fearing they will be targeted. ${ }^{17}$ Control Room, through discourse and editing, reveals the 
competition over the interpretation of events: a struggle of power over the framing of the news.

Captain Rushing is an appealing figure because of his apparent sincerity and his dawning realization that the war is a tragedy. Noujaim treats him sympathetically, focusing on his attractive face in close up. Regardless of the true motives of Bush, Cheney, and Rumsfeld, Rushing seems to have believed sincerely that the U.S. was liberating Iraq and that the collision of the two worlds-Arab and American-could be turned towards their mutual interests. During the course of the film, he comes to see that the war has only spawned more hatred and mistrust. Rushing's hamartia, a Greek term applied to the error in judgment leading to the downfall of the tragic hero, does not lead Rushing himself to suffer a calamitous downfall. ${ }^{18}$ Nevertheless, Rushing's goal -to convince the Arab people that the U.S. is their ally-collapses. The death of Tarek Ayyoub is a reversal (peripitea) that signals the end of this possibility, at least to Rushing. By the end of the film, Rushing recognizes (anagnorisis: the movement from ignorance to knowledge) that he has not learned enough about Arabs. Rushing claims, "We [Americans] don't want to occupy Baghdad." Ibrahim counters, "you are." In response, Rushing says if he gets out of the Marines, he wants to do something with the Palestinian issue. Ibrahim invites Rushing to dinner, signifying Control Room's appeal for ongoing dialogue across cultures.

\section{Representation as War (or War as Representation)}

At its core, war is a means of settling a disagreement, whether that dispute focuses on boundaries, values, or power. If one group of people is strong enough to physically defeat their opponents, they win the war, though their viewpoint may not win the battle for representation.

Twentieth-century philosopher Michel Foucault inverted Clausewitz's phrase "War is politics by other means" to "Politics is the continuation of war by other means." 19 Foucault confronts us with the ways in which arguments, politics, and war are almost inextricably intertwined. Since philosophers present different ideas about the proper form of argumentation, there is no essential or eternal reason why argument and war must be intertwined. Yet the existence of a real war brings out the most eristic of arguments. As Al Jazeera's Sameer Khader says at the beginning of Control Room, "You cannot wage a war without rumors, without media, without propaganda."

In Control Room we perceive a clear metaphor between the war itself and the war of representation-the higher the perceived stakes go, the more fierce the battle for representation and rhetorical dominance becomes. The line between rhetorical eristics and military action is porous indeed. George Lakoff and Mark Johnson theorize that language is metaphorically structured and that our concept of argument is structured in terms of war:

It is important to see that we don't just talk about arguments in terms of war. We can actually win or lose arguments. We see the person we are arguing with as an opponent. We attack his positions and we defend our own. We gain and lose ground. We plan and use strategies. If we find a position indefensible, we can abandon it and take a new line of attack. Many of the things we do in arguing are practically structured by the concept of war. Though there is no physical battle, there is a verbal battle, and the structure of an argument--attack, defense, counterattack, 
etc.--reflects this. It is in this sense that the ARGUMENT AS WAR metaphor is one

that we live by in this culture; it structures the actions we perform in arguing. ${ }^{20}$ lead to different kinds of arguments. For instance, a war might be thought of as a type of game in which a player wins one time but the opponent might win the next. Or war might be imagined as a way to force others to submit to one's will. Finally, war can be imagined as a way to annihilate opponents--like the Punic wars of antiquity, or Hitler's wars. Depending upon which metaphor of war is invoked, a different form of argument develops as a result. The Bush administration and its allies seemed to shift their definition of war as the conflict escalated. To maintain the fiction that its war was about liberation, it had to appear to care about the Iraqi people, yet it also declared its intentions to "take the gloves off," a thinly-veiled threat to use unrestrained violence, it endorsed torture, and it declared free-fire zones in which soldiers were ordered to kill anything that moved.

When Rumsfeld criticizes Al Jazeera for showing Iraqi civilians injured in U.S. bombing attacks, Hassan Ibrahim, a senior producer of Al Jazeera and one of the three main characters of Control Room, points to the hypocrisy of American rhetoric about the war. "You are the most powerful nation on earth, I agree. You can defeat everybody, I agree. You can crush everyone, I agree. But don't ask us to love it as well!" Captain Josh Rushing of CentCom tries to defend against charges that the war is aimed at the Iraqi population by arguing that the U.S. purchased precision bombs at 100 times the cost of conventional bombs in order to minimize civilian casualties. Ibrahim responds, "You're still killing civilians, my friend ... Since Vietnam, the picture has changed. And now in the Arab world, of course, we've come to discover the wonders of television much later than the rest of the world. . . The idea of another Arab capital occupied is really fueling anger." Rushing appears speechless.

Despite their disagreements, Rushing and Ibrahim engage in dialogue with each other, and Rushing seems to change his beliefs when challenged. Warlike arguments, by contrast, seldom encourage other people to hear one's point of view. While there is clearly a proper role for warlike arguments in news and documentary, ${ }^{21}$ there should also be space for dialogue as well. Dialogue makes argumentation a supportive communicative endeavor. Rather than thinking of arguments as wars in which we "attack" our opponents, causing them to "dig in," "retrench," and "put up their defenses," we could think of argumentation as a form of cooperative teaching, in which we employ such ethical forms of persuasion as modeling, reflecting, and giving feedback. Such cooperative efforts occur many times among the characters featured in Control Room. Noujaim films the dialogues of Al Jazeera personnel involved in the making of the news, she films dialogues among opponents such as Ibrahim and Rushing, and she captures dialogues that occur via a single character, such as the moment when Rushing notices his own bias regarding American casualties versus Iraqi casualties. Noujaim is trying to persuade her audience that dialogue is possible and desirable during war. Such dialogue, however, requires a safe space and willing participants. Ironically, Control Room opens a space for dialogue in the heart of the media agora during a war.

34

In ancient Greece, public arguments occurred in the agora, or marketplace. The agora ostensibly provided a forum for argumentation and the rational exchange of ideas that shifted the means of battle from armed conflict to verbal conflict, but Plato was 
suspicious of the argumentation in the agora because the winners were often Sophists who knew how to win by distorting the truth. ${ }^{22}$ Plato wanted to take discourse out of the brutal marketplace of ideas and create spaces of dialogue in which interlocutors traded souls, or at least traded one another's viewpoints. ${ }^{23}$ For Plato, debate should be structured as a dialogue among allies who share a common quest for the truth, not as a winner-take-all war. ${ }^{24} \mathrm{Al} \mathrm{Jazeera} \mathrm{is} \mathrm{a} \mathrm{news} \mathrm{organization,} \mathrm{not} \mathrm{a} \mathrm{philosophy} \mathrm{club,} \mathrm{and} \mathrm{thus}$ does not abide by Plato's ideal. Khader is keen for Al Jazeera to stick to the facts-in one scene he berates a staffer for putting an anti-American diatribe on the air. Control Room, however, is far more philosophical, showing us scenes in which the participants ask each other to trade views, as when Ibrahim reminds Rushing to think about how Arabs view images of civilian casualties.

Though Control Room captures the reality of the journalist as agon, the film itself promotes an ethos not of eristics, but of dialogue. It presents a model of public deliberation grounded in reasonableness and balance in opposition to bellicose and extreme rhetoric. Muafak Tawfik, a translator for Al Jazeera, seems to speak for Noujaim when he says ruefully that the war is radicalizing people: "There'll be no more room for people like me who speak softly and rationally." The greatest irony of Noujaim's film is that the model of thoughtful public discourse she champions-carried on by the film's trio of central characters, Al Jazeera's Ibrahim and Khader and CentCom's Rushing-occurs in private, off the air. Without Noujaim's film we would not have learned of their ambivalences, their doubts, and their struggles to make sense of the catastrophe unfolding around them. If these characters had broadcast their ambivalences over the airwaves, their comments might have cost them their jobs. In other words, dialogue still flickers during wartime, but usually off the air. In the arena of public opinion, dialogue has little to no room during war.

36 As an independent film, Control Room can reach an audience that seeks an alternative to the bellicose rhetoric of the mainstream media agora. Noujaim's effort to bring the thoughtful private deliberations of Ibrahim, Khader, and Rushing to the public seems worthy. In the face of tremendous propaganda and abuses from Bush's neoconservative cabal, Middle Eastern autocrats, and Islamic extremists, thoughtful deliberation is practically lost. Such discourse is too quiet to be heard above the shouting, the noise, and the violence, and those who most need to hear it-those caught up in the narratives of Manichean struggle-are the least likely to hear it. Additionally, our journalism apparatus does not support such dialogue, but instead encourages flag waving, shouting and polarization.

37 Makers of war documentaries face numerous choices. Among these is the decision to favor either eristics or dialogue in their presentation. Each has its strengths and weaknesses. Noujaim's film promotes dialogue as an attractive alternative to propaganda. Yet thoughtful deliberation may take too long during times of crisis and it is too quiet to cut through the noise of the propaganda machines. Other documentary films about the Iraq war, such as Fahrenheit 911, WMD: Weapons of Mass Deception, Hijacking Catastrophe: 9/11, Fear \& the Selling of American Empire, The War You Don't See, and Uncovered: The War on Iraq try to do just that. They take strong advocacy positions, making arguments against the war that they intend to win. They marshal evidence, experts, powerful rhetorical skills, and compelling sights and sounds to cut through the noise and to address the many catastrophes-in government and in the media-that both led to the war and followed from it. 
hoping to promote a global democratic public sphere might desire a referee who could ensure fair play in the media agora, but that ideal seems remote. Also remote is the possibility for a dialogic space to emerge in the midst of the agora, though Control Room's Ibrahim and Rushing show that it is possible. Until we have a viable alternative media universe, refereeing the existing media players and promoting dialogue may be our next best hopes. And until that goal is met, fighting eristics with eristics--fire with fire--is, regrettably, the most effective option remaining to us.

\section{War Documentary and the Public Sphere}

Most documentarians making films about the Iraq War seem driven by a desire to improve the public sphere by offering information and perspectives censored from corporate and government controlled media outlets. These filmmakers promote the values of transparency, of public participation, and of reasonableness. They are often shocked and angry at the scenes they witness, yet many maintain an ethos of fairness and reasonableness. Despite their best efforts to protect, enhance, and expand the public sphere, the obstacles facing makers of independent war documentaries are substantial. Not only do they have trouble gaining access to information, ${ }^{25}$ they also face great physical danger, political risks, ${ }^{26}$ and trouble finding distribution. In some ways, independent documentary filmmakers are similar to Al Jazeera, which appears as a scrappy startup with an alternative point of view, many obstacles to overcome, and a desire to find an audience.

Al Jazeera's struggles to create an alternative media perspective reveal a paradox in our system of modern journalism: we need a mediated frame to understand modern war but it is almost inevitable that those who create such frames will wind up inside them, further complicating the picture. The emergence of this paradox is due, in part, to the global 24-hour news and entertainment apparatus that has arisen with the advent of satellite broadcasting and the Internet. As a result of this apparatus, media consumers are now able to access multiple films, multiple channels, and multiple viewpoints. The war of images occurs in real time. Each film and each channel can now re-frame the other's perspective as it provides its own frame for the narrative of the war. No one stands above the fray. Today's postmodern media environment stands in stark contrast to the media environment that existed during World War I, in which images and stories traveled more slowly and there were fewer of them competing in the same arena. In recent years, the battle for control of the media frame has become increasingly complicated, setting up its players-the documentarians, program directors, journalists, and military spokespeople-in a new arena in which they must consider themselves both as raisoneurs (commentators) and as agonists, caught in the stories they try to make.

41 Critics such as Paul Arthur ${ }^{27}$ and Rand Richards Cooper ${ }^{28}$ argue that documentary films which employ authorial voice and establish historical context, such as Michael Moore's Fahrenheit 911, are more relevant than cinéma vérité films like Control Room. For instance, Control Room does little to contextualize the events it portrays. ${ }^{29}$ Arthur writes:

We receive scant instruction on [Al Jazeera's] previous history, the size of its staff, number of bureaus, sources of funding, daily programming schedule, to say nothing of the role of religion in editorial and content decisions, the status of women, and so on. Indeed, even processes by which stories are assigned, gathered, edited, and 
produced are beyond Control Room's narrow scope. Nor are we privy to the institutional structure or divisions of labor at CentCom. The lack of such information signals a disinterest in precisely the sort of contextual description that can lead to informed, 'big picture' judgments. ${ }^{30}$

Control Room provides limited information about how CentCom tries to control the narrative of the war by manipulating a mostly compliant press, but without a broader context, this information might make little sense to viewers. How much explanation is necessary in a documentary? Bill Nichols cites Bertolt Brecht on this question:

Bertolt Brecht pointed to one kind of excess particularly pertinent to the documentary text when he argued that a photograph of the Krupp munition works does nothing to explain the reality of that enterprise: its forced labor practices, its margin of profit, its ties to the Nazi regime, and so on. Explanation, like narrative, takes time. ${ }^{31}$

Excess-the context that exceeds the frame-is a major factor in our reading of Control Room, which appeals mainly to an audience that already knows something about the war and about the media. As an avid media consumer, I had already seen at least a dozen documentaries about the Iraq War and the political machinations and propaganda campaign leading up to it, had read several books about it, and had read hundreds of articles about it before I watched Control Room. Without background knowledge, an audience viewing Control Room would be less likely to make sense of the war, of the crisis within journalism, or of the need for urgent political action. I found Control Room compelling because it showed me things I didn't know; it revealed the complex lives and choices faced by the media players in the center of the battle for representation. Because it is an on-the-fly cinéma vérité-style film, Control Room uses the power of surprise, often lacking in more didactic films, because we see events unfold and people react to them in the moment.

44 I agree with Arthur that Control Room lacks the framing to contextualize many of the events it portrays. As Arthur points out, Al Jazeera and CentCom may hire "truthseeking" individuals, but this fact tells us almost nothing about the organizations, and without a "more detailed political-economic framework," we are left to make only the most facile of inferences about these organizations. Additionally, Cooper notes that Control Room champions fairness, but with an air of futility. This air of futility is most clearly represented by Sameer Khader's frequent shrugs and his jaded pronouncements, such as "There is one single thing that will be left: victory, and that's it. People like victory. You don't have to justify it. Once you are victorious, that's it." Khader's fatalism does little to encourage its audience to engage in political action.

By contrast, Fahrenheit 911, timed strategically to ambush Bush's 2004 re-election campaign, entertains no doubts either about the wrongness of Bush's actions or about the need for political action, such as voting him out of office, to reverse Bush's agenda. Released in hundreds of theaters across the U.S., Fahrenheit 911 garnered massive media coverage and had at least some hope of influencing events in the short term. By these criteria, Control Room was a failure.

Perhaps the proper way to view Control Room is to perceive it not as an urgent call to promote dialogue and fairness during the immediate crisis of war, aims that may have been hopeless in any case once the war started, but as a course correction over the long term; once this war is over, the film suggests, individuals, organizations, and nations should strive to engage in more dialogue and to be more fair. However, the film also implies that we just need a few more thoughtful individuals, rather than more 
democratic institutions, to make this change. Though I agree that we need more thoughtful individuals and believe that Noujaim's film makes an important contribution towards this effort, I believe documentary can and should do more to bring about a long-term course correction. Documentary can and should support a global democratic public sphere. It can and should examine institutions, and when necessary, call for their reform. But the means to instituting such a deliberative public sphere might require both dialogue and eristics.

In order to magnify the didactic power of his documentaries, a filmmaker such as Michael Moore, who owes much to John Grierson, ${ }^{32}$ tends to use many of the same tactics as the propagandists he opposes. Though Moore does not share Grierson's allegiance to the state, he does tell his audience what to think about and how to think about it. As Cooper notes, Moore, in battling the Bush administration's propaganda, "fights fire with fire." ${ }^{33}$ Noujaim, by contrast, focuses primarily on the conflicts faced by her characters rather than on arguments. In letting viewers decide what to think, she sacrifices most of the director's didactic power. At their extremes, the didactic/ advocacy tradition undermines the democratic values it purports to nurture, while the cinéma vérité tradition is more democratic in terms of its means but may be less effective in the face of propaganda. Of course, it is too easy to posit a false dichotomy here. There are filmmakers who work across both traditions.

Noujaim comes closest to such a hybrid style when responding to Donald Rumsfeld, who complains that Al Jazeera plays propaganda: "What they do is is when there's a bomb goes down, they grab some children and some women and pretend that the bomb hit the women and the children." Noujaim cuts away from Rumsfeld to show television images of severely injured children, making Rumsfeld appear to lie. Sameer Khader replies, "We wanted to show that any war has a human cost." Noujaim's sequence implies a thesis and refutation, but without a formal argument. Instead, Control Room stays mainly in the cinéma vérité tradition:

The chief virtue of Noujaim's version, aside from the up-close-and-personal take on three striking personalities, is its allegorical defense of a tradition of independent documentary ostensibly free of government or corporate coercion. That is, if the elaborated contrast between putatively democratic American network news and state-sponsored reporting at Al Jazeera is shown to be misguided at best, and possibly inverted, Noujaim's own cinematic method and implied mode of circulation is validated internally not just as an alternative to the two disparate media systems under consideration but as superior to them in freedom of expression, ability to elicit identification with its subjects, and in the liberal values that undergird its creative process. In short, to the extent that CNN or Fox News fall short of achieving the goal of true independence, and to the extent that Al Jazeera struggles mightily to do the same, cinéma vérité as practiced by the likes of Noujaim is proposed as redeeming the promise of an ecumenical, 'un-controlled' cinema. ${ }^{34}$

A documentary filmmaker, no matter which style he or she chooses, can encourage the audience to raise productive questions or can work to diminish them. Control Room, perhaps inadvertently, does the latter on occasion. For instance, American media during the Iraq War almost never showed images of Iraqi civilian casualties, of American prisoners of war, or of American dead. Al Jazeera showed all of these things. Control Room might have raised questions about American media policies, how they have changed, what forces were at work in changing them, and what the consequences of such changes have been. By focusing on individual characters rather than on 
policies, the film steers us away from questions about these institutions. ${ }^{35}$ Without understanding the forces of history, audiences have little hope of changing them.

A global democratic public sphere requires a theoria, which was a group of trusted witnesses in ancient Greece who provided an official version of events that would become the basis of public deliberation. The collapse of journalistic integrity in America-represented most dramatically by New York Times reporter Judith Miller's bogus reporting about Iraq's supposed WMD, which she basically transcribed from Dick Cheney's misinformation campaign-has made the need for a new theoria, one free of state control but rigorous and uncompromising, all the more pressing. ${ }^{36}$ As new media entities such as Al Jazeera enter the fray, they become part of the story themselves. Documentary film can contextualize this battle for hegemony of representation, but they cannot escape it. Moore's Fahrenheit 911 provided some context, but became controversial when pro-war partisans attacked it. Unlike Fahrenheit 911, Control Room remained relatively uncontroversial and did not become a major part of the story it covered. Seen in conjunction with Moore's film, as well as those by Greenwald, Schecter and others, Control Room appears as part of a movement within documentary that challenges propaganda and points in the direction of a new theoria and a more democratic and more global public sphere.

Viewers also have a role to play in creating a more democratic and global public sphere. Armed with an ethical sense, some training in rhetoric and poetics, and additional historical research into the relevant institutions, viewers should be better able to navigate the competing media frames and narratives about both war and the war of representation. A more critical media audience will demand a more critical media.

\section{BIBLIOGRAPHY}

Arthur, Paul. "Control Room," Cineaste (Fall 2004): 44-6.

"The Battle for the Control of the Press," The Yurica Report, 2005. http://www.yuricareport.com/ Media/BattleForControlOfThePress.html. <Accessed November 10, 2013>.

Cooper, Rand Richard. “At War: 'Fahrenheit 911' and 'Control Room.”' Commonweal 131 no14, (August 13 2004): 26-7.

el-Nawawy, Mohammed and Adel Iskandar. Al-Jazeera: How the Free Arab News Network Scooped the World and Changed the Middle East. Boulder: Westview Press, 2002.

Fisk, Robert. “No Wonder Al-Jazeera Was a Target.” The Independent. October 26, 2005.

Foucault, Michel. "Society Must Be Defended": Lectures at the Collège de France, 1975-76. New York: Picador, 2003.

Goffman, Erving. The Presentation of Self in Everyday Life. New York: Anchor Books, 1959.

Kahn, Richard and Douglas Kellner. "Oppositional Politics and the Internet: A Critical/

Reconstructive Approach." Cultural Politics, Vol 1. No. 1 (2005): 75-100. 
Kamiya, Gary. "Iraq: Why the Media Failed," Salon Magazine, April 10, 2007, http:// www.salon.com/opinion/kamiya/2007/04/10/media_failure/print.html. <Accessed May 7, 2013>. Lakoff, George and Mark Johnson. Metaphors We Live By. Chicago: University of Chicago Press, 2003.

Lynch, Marc. Voices of the New Arab Public: Iraq, al-Jazeera, and Middle East Politics Today. New York: Columbia University Press, 2005.

Miles, Hugh. Al Jazeera: The Inside Story of the Arab News Channel That Is Challenging the West. New York, Grove Press, 2005.

Morford, Mark. “The Big Lie of Jessica Lynch,” The San Francisco Chronicle, September 5, 2003.

Nichols, Bill. "Documentary Film and the Avant-Garde," Critical Inquiry, Vol. 27, No. 4, (Summer, 2001): 580-610.

Nichols, Bill. Representing Reality. Bloomington: Indiana University Press, 1991.

Plato. The Euthydemus. Cambridge University Press, 2013.

Rampton, Sheldon and John Stauber. Weapons of Mass Deception: The Uses of Propaganda in Bush's War on Iraq. New York: Tarcher Penguin, 2003.

Sarvan, Charles Ponnuthrai,. "Revisiting Foucault: War in Peace and the Question of 'Power," in Journalists for Democracy in Sri Lanka (August 10, 2012), http://www.jdslanka.org/index.php/ 2012-01-30-09-31-17/reflections/166-revisiting-foucault-war-in-peace-and-the-question-ofpower. <Accessed May 7, 2013>.

Schiller, Herbert. "The Corporation and the Production of Culture," in Culture, Inc.: The Corporate Takeover Of Public Expression. New York: Oxford University Press, 1989.

Schiller, Herbert. The Mind Managers. Boston: Beacon Press, 1975.

Tatham, Steve. Losing Arab Hearts \& Minds: The Coalition, Al-Jazeera \& Muslim Public Opinion. London: Hurst \& Co, 2006.

Zayani, Mohamed. The Al Jazeera Phenomenon: Critical Perspectives On New Arab Media. Boulder: Paradigm Publishers, 2005.

\section{NOTES}

1. Charles Ponnuthrai Sarvan, "Revisiting Foucault: War in Peace and the Question of 'Power,"' in Journalists for Democracy in Sri Lanka, August 10, 2012, http://www.jdslanka.org/index.php/ 2012-01-30-09-31-17/reflections/166-revisiting-foucault-war-in-peace-and-the-question-ofpower. Accessed May 7, 2013.

2. Jessica Lynch had already been rescued by Iraqis before the raid by U.S. troops. Mark Morford, "The Big Lie of Jessica Lynch," The San Francisco Chronicle, September 5, 2003.

3. Herbert Schiller, The Mind Managers (Boston: Beacon Press, 1975).

4. Herbert Schiller, "The Corporation and the Production of Culture," in Culture, Inc.: The Corporate Takeover Of Public Expression (New York: Oxford University Press, 1989).

5. See for example Richard Kahn and Douglas Kellner, "Oppositional Politics and the Internet: A Critical/Reconstructive Approach," Cultural Politics, Vol 1. No. 1 (2005).

6. Bill Nichols, Representing Reality (Bloomington: Indiana University Press, 1991), 134-164.

7. Nichols, Representing Reality, 122.

8. Erving Goffman, The Presentation of Self in Everyday Life (New York: Anchor Books, 1959). 
9. In October 2002, 66\% of Americans believed-falsely-that Saddam Hussein was involved in the 9/11 attacks. $79 \%$ believed-falsely-that Iraq already had or would soon have nuclear weapons. Sheldon Rampton and John Stauber, Weapons of Mass Deception: The Uses of Propaganda in Bush's War on Iraq (New York: Tarcher Penguin, 2003, 78-9). In May 2003, 79\% of Americans believed the war was justified. Dana Milbank and Jim VandeHei "Washington Post May 1, 2003 Gallup poll," The Washington Post, May 17, 2003. In less than two years, support for the war nearly collapsed, with majorities believing that the war was not worth the cost, that it should not have been fought, that they disapproved of the way the Bush administration handled the war, and that the U.S. went to war on incorrect assumptions. Dana Milbank and Claudia Deane, "Poll Finds Dimmer View of Iraq War, 52\% Say U.S. Has Not Become Safer," The Washington Post, June 8, 2005.

10. Bush officials frequently stated they were preventing Iraq from attacking Americans in another $9 / 11$ type of attack.

11. Among the Bush administration's media manipulation tactics were the following: creating fake news to be distributed through the media; bribing journalists; criticizing all dissenting reports as politically motivated; placing friendly journalists in front of press conferences while ignoring journalists who ask challenging questions; consolidating media control; making large areas of government policy secret; embedding reporters with troops; and placing Kenneth Tomlinson, a highly partisan operative, in charge of the Corporation for Public Broadcasting. “ The Battle for the Control of the Press," The Yurica Report, 2005. Control Room does not engage these issues directly. It is up to viewers to find out on their own.

12. He argued that Iraqis were moving supposed victims to sites of American attacks in order to frame the Americans.

13. Whenever we hear the words of Bush or Rumsfeld in Control Room, the irony and hypocrisy is thick enough to cut with a knife.

14. In 2006, Al Jazeera International hired Rushing as a commentator, after the Pentagon banned him from giving interviews to the press, as he had done during the filming of Control Room.

15. Al Jazeera had an audience of around 40 million at the start of the Iraq war. It no longer seems small; it has since grown to employ thousands and reaches an audience of hundreds of millions.

16. Al Jazeera was no friend of Saddam, either. Control Room includes a clip of Saddam's information minister complaining that Al Jazeera plays American propaganda.

17. See Robert Fisk, "No Wonder Al-Jazeera Was a Target," The Independent, October 26, 2005. Fisk has no doubt the attack was meant to silence Al Jazeera.

18. He gets a promotion from lieutenant to captain at some point during the film.

19. Michel Foucault, "Society Must Be Defended": Lectures at the Collège de France, 1975-76 (New York: Picador, 2003),15.

20. George Lakoff and Mark Johnson, Metaphors We Live By (Chicago: University of Chicago Press, 2003), 4.

21. At the very least, we need warlike arguments to defend against those used against us by propagandists.

22. Plato's characterized version of Socrates targets the Sophists as deceivers, though it remains unclear whether his portrayal of the Sophists is accurate; few Sophist texts survive. Nevertheless, the term Sophist has taken on a pejorative meaning today. The expert deceivers of today create what Boorstin refers to as media events, which are events that exist solely to create publicity. The toppling of the Saddam statue appears to be just such an event. These media events are adopted into the media agora often with glee from media outlet themselves, who are always looking for a good story and good pictures.

23. Though Socrates participated in the marketplace, he exposed its supposedly wise men, such as Protagoras, as frauds. In Phaedrus, Socrates participated in a more ideal setting for dialogue: outside the city walls with only one interlocutor. 
24. Ironically, the Greek culture that allowed for the luxury of dialogue was founded on brutal wars of conquest and on slavery.

25. Noujaim's initial request to Al Jazeera to document their newsroom was declined.

26. Laura Poitras, director of My Country, My Country, a 2006 film about life in Iraq under U.S. occupation that was nominated for an Academy Award, was placed on the Department of Homeland Security's terror watch list and has been detained and harassed by government agents for years.

27. Paul Arthur, "Control Room," Cineaste (Fall 2004), 44-6.

28. Rand Richards Cooper, "At War: 'Fahrenheit 911' and 'Control Room,'” Commonweal, Vol. 131, No. 14, August 13 2004, 26-7.

29. Given the relative brevity and limited aims of this article, I prefer to omit this larger context here and to refer the reader to numerous books telling the "big picture" Al Jazeera story. Among them are:

Marc Lynch, Voices of the New Arab Public: Iraq, al-Jazeera, and Middle East Politics Today (New York: Columbia University Press, 2005).

Hugh Miles, Al Jazeera: The Inside Story of the Arab News Channel That Is Challenging the West (New York, Grove Press, 2005).

Mohammed el-Nawawy and Adel Iskandar Al-Jazeera: How the Free Arab News Network Scooped the World and Changed the Middle East (Boulder: Westview Press, 2002).

Steve Tatham, Losing Arab Hearts \& Minds: The Coalition, Al-Jazeera \& Muslim Public Opinion (London: Hurst \& Co, 2006).

Mohamed Zayani, The Al Jazeera Phenomenon: Critical Perspectives On New Arab Media (Boulder: Paradigm Publishers, 2005).

30. Paul Arthur, "Control Room," Cineaste (Fall 2004), 45.

31. Bill Nichols, Representing Reality (Bloomington: Indiana University Press, 1991), 143.

32. Bill Nichols, in "Documentary Film and the Avant-Garde," summarizes the didactic tradition: Grierson championed long and hard for a documentary film practice that persuaded more than informed, guided more than observed. The social orator undertook the task of offering moral and political guidance to the confused masses by means of emotionally (rhetorically) compelling argument. Fulfillment lay in carrying out one's responsibilities to the common goals embodied in the nation-state. Grierson's discussions of meanings and values, virtues and models, never occurred in a realm of timeless contemplation. They played a crucial role in developing what Foucault would call "strategies of domination" in relation to the alternatives posed by the European avant-garde and the Soviet model. Critical Inquiry, Vol. 27, No. 4 (Summer, 2001), 600.

33. Rands Richard Cooper, "At War: 'Fahrenheit 911' and 'Control Room,'” Commonweal, Vol. 131, No. 14, August 13, 2004, 27.

34. Paul Arthur, "Control Room," Cineaste (Fall 2004), 45.

35. For instance, Al Jazeera was started with a loan from the Emir of Qatar, Sheikh Hamad bin Khalifa. How much influence, if any, did the Emir have on the network's reporting?

36. I recommend the following article for an analysis of the U.S. media's collapse: Gary Kamiya, "Iraq: Why the Media Failed," Salon Magazine, April 10, 2007, http://www.salon.com/opinion/ kamiya/2007/04/10/media_failure/print.html 


\section{ABSTRACTS}

This essay assesses Control Room (Jehane Noujaim, 2004) to gauge documentary film's capacity to restore the public sphere. What factors shape the making of news during times of war? How can viewers learn to navigate the competing media frames and narratives about war? How can dedicated documentarians make more democratic a public sphere that has been badly damaged by corporate media consolidation and government propaganda? Finally, can rhetoric and poetics shed light on the choices made by documentary filmmakers during times of war and the ways in which target audiences are expected to make sense of their films?

INDEX

Keywords: Cinéma Vérité, Iraq War, Al Jazeera, journalism, drama

\section{AUTHOR}

\section{BARRY MAUER}

Barry Jason Mauer teaches in the Texts and Technology Ph.D. Program at the University of Central Florida and is associate professor in the English Department, where he has served since 1999. His published work focuses on developing new research practices in the arts and humanities. 